\title{
Analisis Pengaruh Waktu Sputtering Pd dan Ni pada Sintesis Material Elektrokatalis Berbahan Pd-Ni/Graphene terhadap Unjuk Kerja Direct Methanol Fuel Cell (DMFC)
}

\author{
Yogi Nuriana, Diah Susanti, Hariyati Purwaningsih, dan Tri Mardji Atmono \\ Jurusan Teknik Material \& Metalurgi, Fakultas Teknologi Industri, Institut Teknologi Sepuluh Nopember (ITS) \\ Jl. Arief Rahman Hakim, Surabaya 60111 Indonesia \\ e-mail: santiche@mat-eng.its.ac.id
}

\begin{abstract}
Abstrak - Direct Methanol Fuel Cell (DMFC) memiliki potensi untuk dikembangkan dengan menambahkan graphene sebagai material pendukung katalisnya karena luas permukaannya yang tinggi. Kemudian kinerjanya juga dapat ditingkatkan dengan penambahan logam yang sesuai seperti Nikel. Tujuan penelitian ini ialah menganalisa pengaruh waktu sputtering pada sintesis material elektrokatalis berbahan graphene/Pd-Ni terhadap unjuk kerja DMFC. Graphene diperoleh dari grafit yang dioksidasi menggunakan metode Hummer kemudian direduksi dengan serbuk $\mathrm{Zn}$ dan proses hidrotermal selama 12 jam pada temperatur $160^{\circ} \mathrm{C}$. Kemudian didepositkan pada carbon cloth lalu dilapisi dengan logam Pd dan/atau Ni selama 15, 10 dan 5 menit dengan metode radio-frequency sputtering. Hasil penelitian menunjukkan waktu sputtering $\operatorname{Pd}(10)$ dan $\operatorname{Pd}(15)-N i(5)$ memberikan hasil terbaik dengan nilai kapasitansi spesifik 32,86 F/g dan 23,30 F/g, Electrochemical active surface area (ECSA) sebesar $0,747 \mathrm{~m}^{2} / \mathrm{g}$ dan $0,371 \mathrm{~m}^{2} / \mathrm{g}$ berdasarkan pengujian cyclic voltametry $(\mathrm{CV})$ pada larutan $\mathrm{KOH} 1 \mathrm{M}$. Sedangkan pengujian pada elektrolit $\mathrm{KOH}+\mathrm{CH}_{3} \mathrm{OH} 1 \mathrm{M}$ menghasilkan rasio $\mathrm{I}_{\mathrm{f}} / \mathrm{Ib}_{\mathrm{b}} \mathbf{2 3 , 5}$ dan 47,36 serta densitas arus sebesar $4,80 \mathrm{~mA} / \mathrm{g}$ dan $4,18 \mathrm{~mA} / \mathrm{g}$.
\end{abstract}

Kata Kunci-DMFC, Graphene, Pd, Ni, Sputtering.

\section{PENDAHULUAN}

$\mathrm{P}$ ERMASALAHAN energi yang terus meningkat akibat tergantungnya kebutuhan energi manusia pada pemakaian bahan bakar fosil yang semakin menipis dan menghasilkan emisi gas yang mencemari lingkungan menuntut sumber energi baru yang minim emisi, murah, tersedia dalam jumlah tak terbatas, dan ramah lingkungan. Salah satu energi terbarukan yang dapat dikembangkan saat ini ialah fuel cell. Fuel cell serupa dengan baterai yang menghasilkan listrik dari reaksi elektrokimia. Sebuah fuel cell menggunakan suplai eksternal dari energi kimia dan dapat berjalan tanpa batas waktu, selama sumber bahan bakarnya masih disuplai, yakni hidrogen dan oksigen. Terdapat beberapa jenis fuel cell berdasarkan elektrolit ataupun bahan bakar utamanya, salah satunya Direct Methanol Fuel Cell (DMFC). DMFC merupakan fuel cell dengan membran polimer dan menggunakan bahan bakar metanol. DMFC merupakan salah satu fuel cell yang dapat beroperasi pada temperatur rendah dan kualitasnya seperti performa, durabilitas, dan efisiensi, sangat dipengaruhi oleh material elektrokatalisnya. Material yang digunakan fuel cell sebagai elektrokatalis, yaitu material berbasis platinum, rutenium, dan paladium.

Paladium memiliki lebih banyak keunggulan dibandingkan rutenium dan platina karena dapat secara luas digunakan dalam fuel cell, harganya yang jauh lebih murah, dan memiliki ketersediaan yang lebih banyak walaupun memiliki oxygen reduction reaction (ORR) yang lebih rendah [1]. Selain itu untuk meningkatkan efektivitas katalis, dapat digunakan material lain sebagai pendukung salah satunya material berbasis karbon. [2]. Dibandingkan dari semua bentuk grafit, graphene memiliki potensi yang lebih menjanjikan. Graphene memiliki beberapa sifat yang baik, antara lain, mobilitas muatan yang tinggi $\left(230.000 \mathrm{~cm}^{2} / \mathrm{V}\right.$-s), konduktivitas termal yang tinggi (3000 W/m-K), dan luas permukaan yang besar $\left(2600 \mathrm{~m}^{2} / \mathrm{g}\right)$ [3]. Dengan demikian, graphene sesuai untuk meningkatkan efisiensi kerja DMFC sebagai material pendukung elektrokatalisnya. Pada penelitian ini akan dibahas pengaruh penambahan nikel pada elektrokatalis berbahan Pd$\mathrm{Ni}$ /Graphene dalam meningkatkan aktifitas elektrokimia dalam reaksi oksidasi metanol.

\section{METODE PENELITIAN}

\section{A. Sintesis Graphene}

Graphene disintesis dari oksidasi grafit menjadi grafit oksida menggunakan metode Hummer kemudian direduksi menggunakan serbuk $\mathrm{Zn}$ kemudian dihidrotermal selama 12 jam pada temperatur $160^{\circ} \mathrm{C}$.

Sintesis grafit oksida dimulai dengan melarutkan 2 gram serbuk grafit dengan $80 \mathrm{~mL}$ larutan $\mathrm{H}_{2} \mathrm{SO}_{4}$, kemudian menambahkan 4 gram $\mathrm{NaNO}_{3}$ dan 8 gram $\mathrm{KMnO}_{4}$ secara bertahap dan bergantian. Kemudian pengadukan dilanjutkan pada temperatur $35^{\circ} \mathrm{C}$ selama $20 \mathrm{jam}$. Lalu menambahkan 200 $\mathrm{mL}$ aquades dan ditambahkan $\mathrm{H}_{2} \mathrm{O}_{2} 20 \mathrm{~mL}$. Selanjutnya larutan dipisahkan menggunakan centrifuge kemudian endapan dicuci menggunakan $\mathrm{HCl} 35 \%$ untuk menghilangkan ion-ion logam yang tersisa. Proses pencucian selanjutnya menggunakan aquades secara berkala untuk menetralkan $\mathrm{pH}$. Selanjutnya untuk menguji ion sulfat telah hilang dan $\mathrm{pH}$ netral, dilakukan titrasi dengan $\mathrm{BaCl}_{2} 1 \mathrm{M}$ dan kertas $\mathrm{pH}$. Kemudian proses drying dalam wadah crucible alumina dalam muffle furnace pada temperatur $110^{\circ} \mathrm{C}$ selama $12 \mathrm{jam}$.

Pembuatan graphene dimulai dengan melarutkan $40 \mathrm{mg}$ grafit oksida ke dalam $40 \mathrm{~mL}$ aquades, kemudian dilakukan 
pengadukan dan ultrasonikasi selama 120 menit. Kemudian grafit oksida direduksi menggunakan serbuk $\mathrm{Zn}$.. Tahapannya ialah dengan menambahkan $10 \mathrm{~mL} \mathrm{HCl}(35 \%)$ ke dalam larutan grafit oksida dalam kondisi non-stirring. Kemudian menambahkan serbuk Zn sebanyak 1,6 gram dan dilakukan pencucian menggunakan $\mathrm{HCl} 5 \%$ untuk menghilangkan sisa ion logam. Kemudian dilanjutkan pencucian menggunakan aquades beberapa kali untuk mendapatkan $\mathrm{pH}$ netral (mendekati 7). Endapan dimasukkan dalam autoclave untuk dilakukan proses hidrotermal dalam muffle furnace pada temperatur $160^{\circ} \mathrm{C}$ selama 12 jam.

\section{B. Sintesis Katalis Pd-Ni/Graphene}

Sintesis katalis $\mathrm{Pd}-\mathrm{Ni} /$ Graphene dimulai dengan melarutkan Graphene sebanyak $40 \mathrm{mg}$ dalam $40 \mathrm{ml}$ aquades kemudian mendepositkan larutan Graphene pada carbon cloth dengan metode ultrasonikasi sehingga terbentuk Graphene yang tersebar pada carbon cloth. Crabon cloth yang telah terdeposit oleh graphene ini selanjutnya dikeringkan selama 24 jam pada temperatur ruang. Kemudian dilanjutkan dengan melapisi carbon cloth dengan logam Pd dan/atau $\mathrm{Ni}$ menggunakan metode Radio-frequency sputtering selama 15, 10 menit, dan 5 menit sehingga terbentuk lapisan thin film $\mathrm{Pd}$ dan/atau Ni yang melapisi carbon cloth.

\section{Preparasi Elektroda Katalis Pd-Ni/Graphene}

Preparasi elektroda dilakukan dengan menyiapkan batang karbon dari baterai berukuran AA. Batang karbon dimasukkan dalam tabung kaca dengan diameter $\sim 0,3 \mathrm{~cm}$ dan panjang $3,5 \mathrm{~cm}$ dengan menyisakan sedikit ruang pada ujung tabung kaca. Batang karbon dan tabung kemudian direkatkan dengan lem secukupnya. Sampel hasil sputtering dipotong kecil-kecil kemudian dimasukkan pada ruang tabung kaca yang sudah disisakan.

\section{Pengujian X-Ray Difraction (XRD)}

Pengujian XRD dilakukan untuk mengetahui perbedaan dari struktur kristal grafit, grafit oksida dan graphene serta pengaruh hasil sputtering logam $\mathrm{Pd}$ dan $\mathrm{Ni}$. Alat yang digunakan X-Ray Difractometer merk Xpert Pro Panlythical dengan sinar $X$ pada sudut $2 \theta=5^{\circ}-90^{\circ}$ dan panjang gelombang $\mathrm{CuK} \alpha$ sebesar $1,5406 \AA$.

\section{E. Pengujian Scanning Electron Miscroscope (SEM)}

Pengujian SEM untuk mengetahui morfologi dari sampel selama proses sintesis dilakukan dengan Scanning Electron Microscope merek FEI Inspect S-50 dengan tegangan 20kV dan perbesaran 5000x serta 10000x.

\section{F. Pengujian Cyclic Voltammerty $(\mathrm{CV})$}

Pengujian elektrokimia dilakukan dengan metode CV menggunakan instrumen EDAQ EChem ER461 dengan elektroda referensi $\mathrm{Ag} / \mathrm{AgCl}$ dan scan rate $0,1 \mathrm{~V} / \mathrm{s}$ dengan rentang $-1 \mathrm{~V}$ sampai $0,5 \mathrm{~V}$ menggunakan elektrolit $\mathrm{KOH}$ dan metanol.

\section{HASIL DAN PEMBAHASAN}

\section{A. Hasil Pengujian XRD}

Gambar 1 dan Tabel 1 menunjukkan perbedaan antara grafit, grafit oksida dan Graphene. Grafit memiliki puncak yang tajam pada posisi $26,44^{\circ}$, dengan intensitas (23408) serta Full Width Half Maximum (FWHM) dan $\mathrm{d}_{\text {spacing }}$ yang kecil yakni 0,0013 dan 3,37. Kemudian setelah dilakukan proses oksidasi, grafit menjadi grafit oksida (GO) dengan terbentuknya puncak pada posisi $12,48^{\circ}$ [4]. Pergeseran puncak ini dapat diindikasikan sebagai transformasi grafit ke grafit oksida. $\mathrm{GO}$ memiliki $\mathrm{d}_{\text {spacing }}$ yang lebih lebar dibanding grafit sebesar 7,09 $\mathrm{A}$. Hasil ini serupa dengan hasil sintesis grafit oksida yang dilakukan oleh Listyana (2016) [5].

Dari hasil XRD menunjukkan bahwa Graphene terbentuk dengan puncak pada posisi $24,28^{\circ}$ serta memiliki FWHM yang cukup lebar dibanding GO dan grafit. Lebarnya FWHM Graphene yang terbentuk menunjukkan bahwa Graphene bersifat amorf.

Gambar 2 dan Tabel 2 menunjukkan hasil XRD pada material katalis Carbon Cloth-Graphene (CC-Graphene), CCGraphene/Ni(15) dan CC-Graphene/Pd(15). CC/Graphene memiliki peak mirip dengan grafit pada $26,9^{\circ}$ dan juga $d_{\text {spacing }}$ sebesar $3,32 \AA$ namun dengan FWHM yang lebih tinggi yaitu 0,064 yang menunjukkan sifat amorf yang juga karena adanya impregnasi graphene seperti dijelaskan Ratnasari (2016)[6].

Setelah di-sputtering dengan Ni selama 15 menit dan disputtering dengan Pd selama 15 menit, tidak terjadi perbedaan 2 Theta atau pun $\mathrm{d}_{\text {spacing }}$ yang signifikan pada peak karbon. Hal tersebut menunjukkan bahwa proses sputtering tidak mengubah struktur kristal. Pada Ni(15) peak Ni tidak muncul hal ini disebabkan lapisan yang terbentuk merupakan thin film sehingga tidak terbaca di XRD. Kemudian muncul peak Pd pada $39^{\circ}$ bidang (111) pada sampel $\mathrm{Pd}(15)$ menunjukkan $\mathrm{Pd}$ berhasil terdeposisi pada CC-graphene[6].

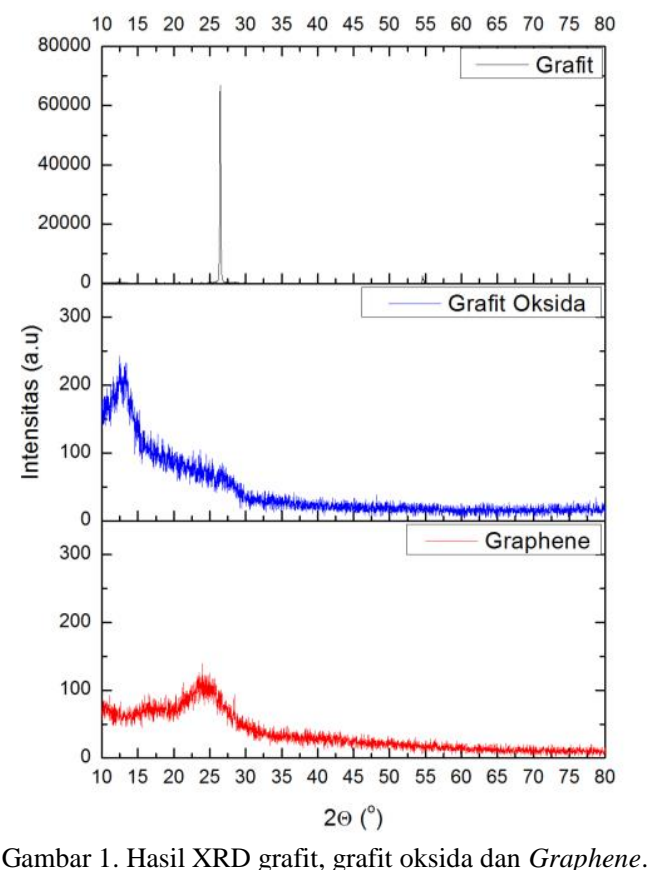


Tabel 1.

Perbandingan Hasil XRD, Grafit, Grafit Oksida dan Graphene.

\begin{tabular}{ccccc}
\hline \hline Material & $\mathbf{2 \theta}\left({ }^{\boldsymbol{(}}\right)$ & $\begin{array}{c}\text { FWHM } \\
(\mathbf{r a d})\end{array}$ & $\mathbf{d}_{\text {spacing }}(\mathbf{\AA})$ & Intensitas \\
\hline Grafit & 26,44 & 0,0013 & 3,37 & 23408 \\
Grafit Oksida & 12,48 & 0,045 & 7,09 & 243 \\
Graphene & 24,28 & 0,074 & 3,66 & 108 \\
\hline \hline
\end{tabular}

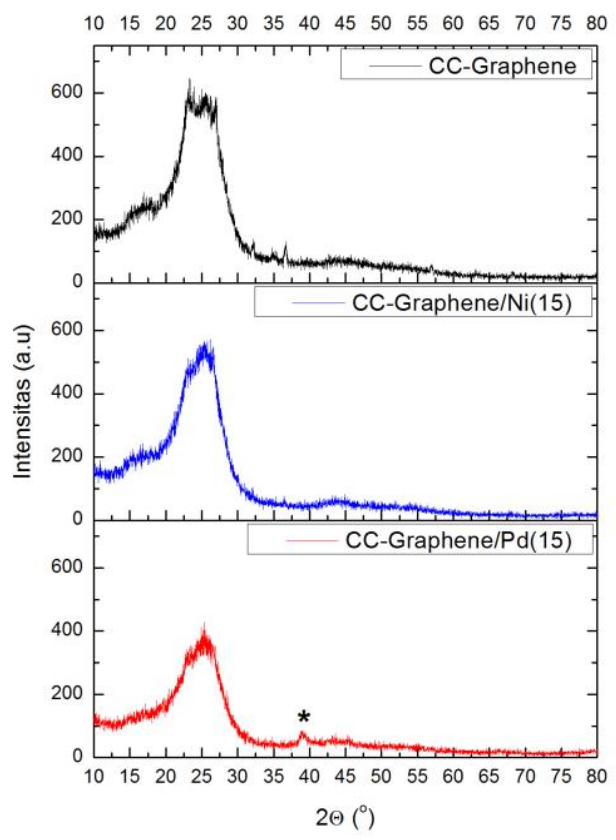

Gambar 2. Hasil XRD CC-Graphene, CC-Graphene/Ni(15) dan CCGraphene/Pd(15).

Analisis XRD pada sampel $\mathrm{Pd}(15)-\mathrm{Ni}(5), \operatorname{Pd}(15)-\mathrm{Ni}(10)$, dan $\operatorname{Pd}(15)-\mathrm{Ni}(15)$ ditunjukan oleh Gambar 3 dan Tabel.2. Terlihat dari tabel tersebut tidak adanya perubahan signifikan dari 2 theta dan $\mathrm{d}_{\text {spacing }}$ dari peak karbon sehingga hal tersebut menunjukkan bahwa proses sputtering yang dilakukan tidak menyebabkan terjadinya perubahan struktur kristal dari graphene.

Hasil pengujian menunjukkan bahwa logam Pd berhasil terdeposisi pada cc-graphene. Sedangkan peak Ni tidak muncur karena proses sputtering dilakukan dengan menggunakan logam Nikel terlebih dahulu kemudian logam Pd sehingga terbentuk lapisan multi thin layer dengan posisi dari bawah ke atas cc-graphene, $\mathrm{Ni}$, dan $\mathrm{Pd}$ dimana lapisan $\mathrm{Pd}$ menutupi Ni.

\section{B. Hasi Pengujian SEM}

Berikut merupakan hasil pengujian SEM morfologi dari grafit, grafit oksida dan Graphene berdasarkan hasil sintesis dengan metode Hummer yang dimodifikasi ditunjukkan pada Gambar 4 berikut. Gambar 4 (a) merupakan morfologi grafit. Hasil SEM pada grafit menunjukkan morfologi nya berupa serpihan (flakes) yang tersebar tidak merata. Grafit yang diamati berupa serbuk yang digunakan pada proses sintesis grafit oksida. Pada Gambar 4 (b) merupakan grafit oksida yang telah dioksidasi dari serbuk grafit. Morfologi grafit oksida berbentuk lembaran bertumpuk dan tebal yang diperoleh dari hasil oksidasi dan drying sehingga lebih tipis dibandingkan grafit. Setelah didapatkan grafit oksida kemudian dilakukan reduksi menggunakan serbuk Zinc, kemudian dilakukan proses ultrasonikasi untuk memecah grafit oksida dan dilakukan proses hidrotermal sehingga terbentuk Graphene. Morfologi graphene terlihat lebih tipis dibandingkan dengan grafit maupun grafit oksida.

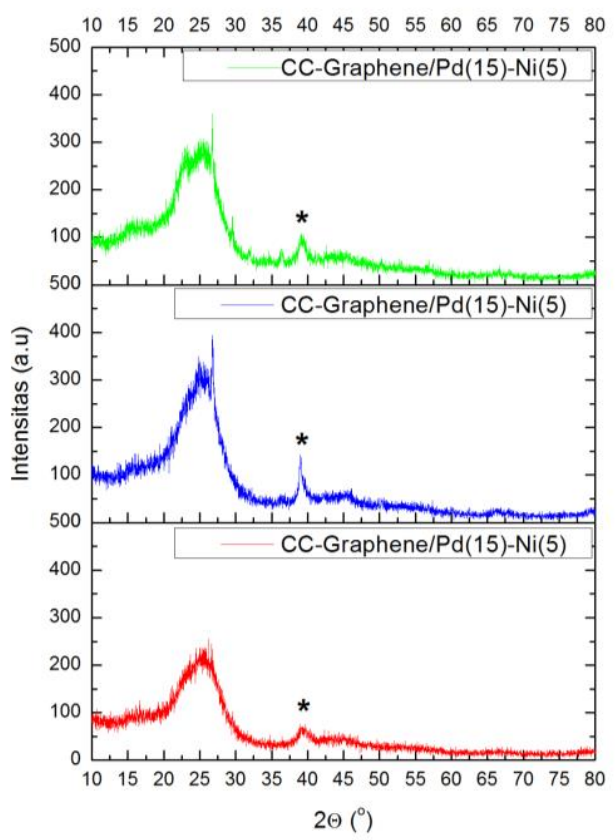

Gambar 3. Hasil XRD CC-Graphene/Pd(15)-Ni(5), CC-Graphene/Pd(15)$\mathrm{Ni}(10)$ dan CC-Graphene/Pd(15)-Ni(15).

Tabel 2.

Perbandingan hasil XRD CC-Graphene, CC-Graphene/Ni15, CCGraphene/Pd(15), dan CC-Graphene/Pd(15)-Ni

\begin{tabular}{cccc}
\hline \hline Sampel & $\mathbf{2 \theta}\left(^{(}\right)$ & $\mathbf{d}_{\text {spacing }}(\mathbf{\AA})$ & Intensitas \\
\hline CC-Graphene & 26,9 & 3,32 & 576 \\
CC-Graphene /Ni(15) & 26,66 & 3,33 & 509 \\
CC-Graphene /Pd(15) & 26,59 & 3,35 & 356 \\
CC-Graphene & 39 & 2,31 & 86 \\
/PdNi(5) & 26,73 & 3,33 & 360 \\
CC-Graphene & 39,22 & 2,23 & 85 \\
/PdNi(10) & 26,78 & 3,33 & 355 \\
CC-Graphene & 26,53 & 2,3 & 142 \\
/PdNi(15) & 39,35 & 3,36 & 211 \\
\hline \hline
\end{tabular}

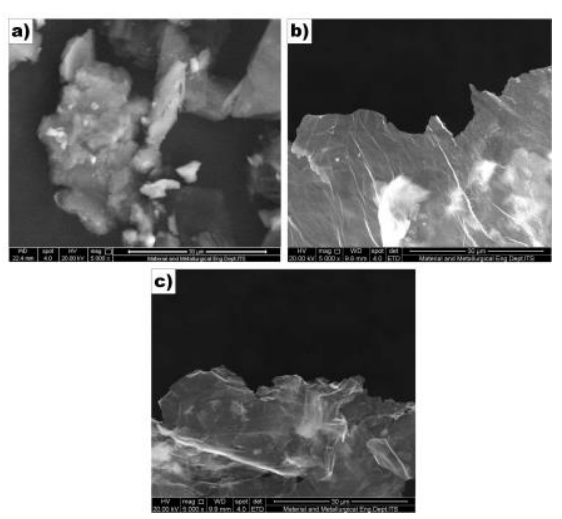

Gambar 4. Morfologi permukaan (a) grafit, (b) grafit oksida, dan (c) Graphene dengan SEM perbesaran 5000x 
Morfologi Carbon cloth sebelum dan setelah diimpregnasi oleh graphene ditunjukkan pada Gambar 5. Gambar 5 (a) menunjukkan morfologi permukaan carbon cloth berupa serat-serat yang dianyam sedangkan Gambar 5 (b) menunjukkan carbon cloth yang telah diimpregnasi dengan Graphene.
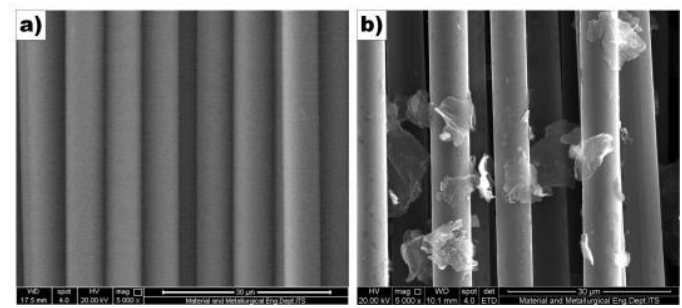

Gambar 5. Morfologi (a) Carbon cloth b) impregnasi Graphene dengan perbesaran $5.000 \mathrm{x}$

Dari hasil SEM, dapat dilihat bahwa Graphene yang diimpregnasi tersebar pada carbon cloth dan menyisip ke dalam serat-serat carbon cloth. Hal ini dikarenakan impregnasi yang dilakukan dengan cara mengultrasonikasinya.

Untuk morfologi Carbon cloth-graphene yang telah dilapisi oleh Pd maupun Ni ditunjukkan pada Gambar 6. Gambar 6 menunjukkan morfologi Carbon cloth-Graphene yang telah disputter dengan Palladium maupun Nikel dengan variasi waktu tertentu. Pd atau Ni yang terdeposit merupakan nanopartikel yang menempel pada permukaan Carboncloth/Graphene. Dapat dikatakan demikian karena proses $R F$ Sputtering sendiri merupakan proses pelapisan yang menembakkan gas Ar pada logam Pd atau Ni sehingga atomatom $\mathrm{Pd}$ atau $\mathrm{Ni}$ terlepas dan melapisi Carboncloth/Graphene. Jika diamati menggunakan SEM, morfologinya sulit diamati karena partikel hasil sputter membentuk thin film sehingga morfologinya menyerupai $\mathrm{CC} /$ Graphene pada Gambar 5. Begitu juga dengan Gambar 7 yang menunjukkan hasi SEM dari cc-graphene yang disputter dengan Ni kemudian Pd secara bergilir dengan waktu sputter $\mathrm{Ni}$ bervariasi dan Pd tetap. Jika diamati dengan lebih teliti memang pada serat carbon cloth dan graphene dari hasil SEM seperti ada lapisan yang menyelimuti yang merupakan thin film logam hasil sputtering. Hasil SEM-EDX yang ditunjukkan oleh Tabel 3 pun menunjukkan adanya kandungan lapisan logam Pd dan Ni.

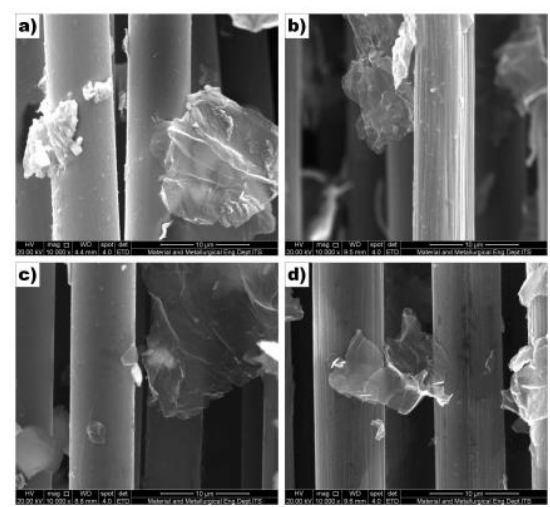

Gambar 6. Morfologi Carbon Cloth-Graphene variasi sputtering (a) $\operatorname{Pd}(15)$ (b) $\mathrm{Pd}(10)$, (c) $\mathrm{Pd}(5)$ dan (d) Ni(15) dengan perbesaran 10000x.
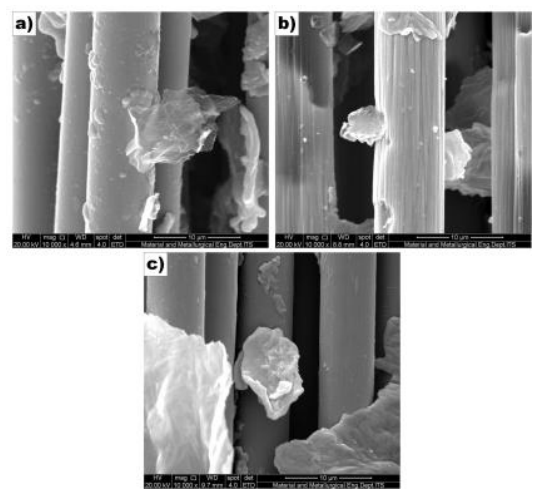

Gambar 7. Morfologi Carbon Cloth-Graphene variasi sputtering (a) $\operatorname{Pd}(15)$ $\mathrm{Ni}(15)$ (b) $\mathrm{Pd}(15)-\mathrm{Ni}(10)$, dan (c) $\mathrm{Pd}(15)-\mathrm{Ni}(5)$ dengan perbesaran 10000x.

Tabel 3.

Data Persen Berat Hasil Uji SEM-EDX elektrokatalis CC-Graphene yang Disputtering dengan Pd dan/atau Ni dengan variasi waktu 5, 10, dan 15 menit.

\begin{tabular}{lcc}
\hline \hline Sampel & Pd $(\% \mathbf{W t})$ & Ni $(\% \mathbf{W t})$ \\
\hline CC-G & - & - \\
CC-G/Ni(15) & - & 21,75 \\
CC-G/Pd(5) & 48,93 & - \\
CC-G/Pd(10) & 61,40 & - \\
CC-G/Pd(15) & 81,88 & - \\
CC-G/Pd(15)-Ni(5) & 76,54 & 01,94 \\
CC-G/Pd(15)-Ni(10) & 59,22 & 03,10 \\
CC-G/Pd(15)-Ni(15) & 37,83 & 10,61 \\
\hline \hline
\end{tabular}

\section{Hasil Pengujian CV}

Perhitungan kapasitansi didapatkan dari hasil pengujian $\mathrm{CV}$ pada elektrolit KOH 1M. Pengujian dilakukan pada Carbon Cloth (CC), CC-Graphene dan CC-Graphene yang di-sputter logam Pd dan/atau Ni menggunakan elektrolit $\mathrm{KOH}$ 1M. Kurva hasil pengujian CV menunjukkan ada aktivitas elektrokimia pada cathodic scan pada CC-Graphene yang disputter Pd namun tidak pada CC, CC-graphene, dan CCGraphene yang di-sputter Ni. Gambar 8 menjelaskan luas kurva semakin membesar dari dari CC < CC-graphene < CCgraphene $/ \mathrm{Pd}(15)<\mathrm{CC}$-graphene $/ \mathrm{Ni}(15)$. Hal tersebut mengindikasikan semakin baiknya sifat kapasitor dari material tersebut. Hal tersebut dibuktikan dengan hasil perhitungan kapasitansi pada Tabel 4.

Gambar 9 menjelaskan kurva hasil uji CV pada sampel CCgraphene yang di-sputter logam Pd dengan variasi waktu sputter 5 menit, 10 menit, dan 15 menit. Pada ketiga kurva tersebut menunjukkan adanyan peak reduksi pada potensial 0,3 sampai -0,6V. Seperti yang disebutkan oleh Kiyani (2015) [7] hal tersebut menunjukkan adanya reaksi reduksi Pd (II) oksida yang terbentuk selama anodic scan akibat teradsorpsinya $\mathrm{OH}^{-}$dipermukaan $\mathrm{Pd}$.

Terjadi penurunan luasan pada $\operatorname{Pd}(15)$ dimungkinkan karena adanya penumpukan Pd seperti yang disampaikan oleh Xi (2013) [8]. Hal tersebut juga dikuatkan oleh hasil uji SEMEDX dimana pada sampel Pd(15) memiliki kandungan Pd sebesar $81,88 \% \mathrm{Wt}$ jauh melibihi kandungan carbonnya sebagai tempat Pd terdeposisi. Sedangkan pada Pd(5) nilainya lebih kecil dari Pd10 karena memang persentase Pd dalam sampelnya pun lebih sedikit. 
Gambar 10 menunjukkan kurva hasil uji CV untuk sampel CC-graphene yang di-sputter dengan nikel kemudian dengan Pd dimana waktu sputtering nikel bervariasi 5 menit, 10 menit dan 15 menit sedangkan Pd konstan 15 menit. Dari hasil tersebut diperoleh luas kurva terbesar ke kecil terdapat pada $\mathrm{Pd}(15)-\mathrm{Ni}(10)>\mathrm{Pd}(15)-\mathrm{Ni}(5)>\mathrm{Pd}(15)-\mathrm{Ni}(15)$ sedangkan nilai kapasitansi terbesar ke kecil $\operatorname{Pd}(15)-\mathrm{Ni}(10)>\operatorname{Pd}(15)-$ $\mathrm{Ni}(15)>\mathrm{Pd}(15)-\mathrm{Ni}(5)$.

Luasan kurva optimal terdapat pada sampel $\mathrm{Pd}(15)-\mathrm{Ni}(10)$, sedangkan pada $\mathrm{Pd}(15)-\mathrm{Ni}(15)$ terjadi penurunan luas kurva hal ini dimungkinkan karena tertutupnya luas permukaan karbon oleh $\mathrm{Pd}$ dan $\mathrm{Ni}$ yang banyak. Hal ini juga yang menyebabkan terjadinya penurunan nilai kapasitansi pada $\mathrm{Pd}(15)-\mathrm{Ni}(15)$.

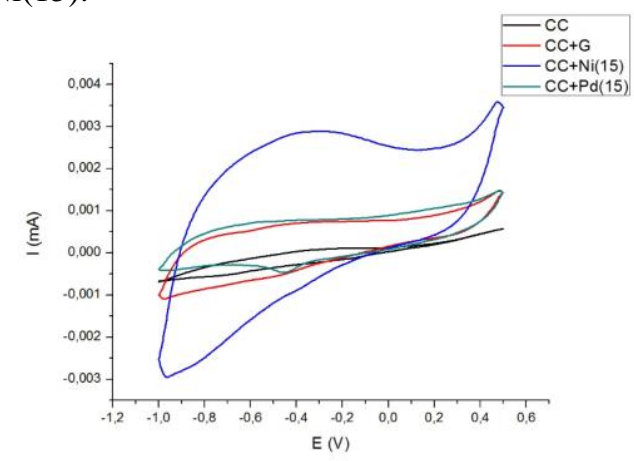

Gambar 8. Kurva hasil pengujian CV pada Carbon Cloth (CC), CCGraphene CC-Graphene/Ni(15), dan CC-Graphene/Pd(15) dalam elektrolit $\mathrm{KOH} 1 \mathrm{M}$.

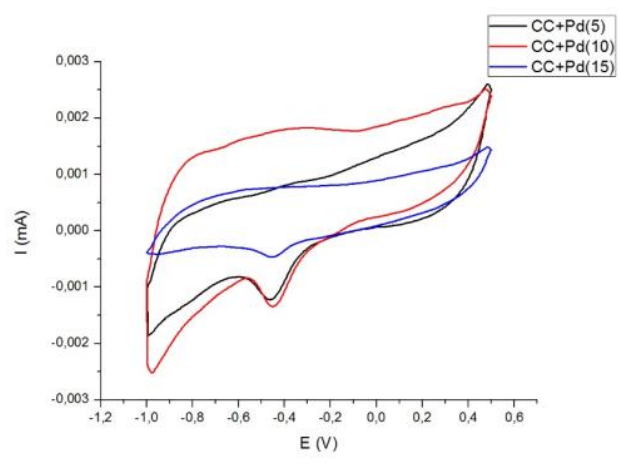

Gambar 9. Kurva hasil pengujian CV pada CC-Graphene/Pd(5), CCGraphene/Pd(10), dan CC-Graphene/Pd(15) dalam elektrolit KOH 1M.

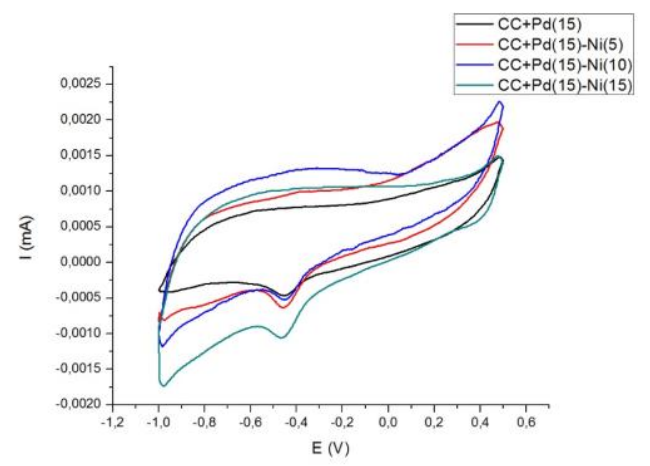

Gambar 10. Kurva hasil pengujian $\mathrm{CV}$ pada $C C$-Graphene/Pd(15), $C C$ Graphene/Pd(15)-Ni(5), dan CC-Graphene/Pd(15)-Ni(10) dan CCGraphene/Pd(15)-Ni(15) dalam elektrolit $\mathrm{KOH} 1 \mathrm{M}$.
Luas permukaan aktif/Electrochemical Active Surface Area (ECSA) merupakan salah satu hal penting dalam menentukan aktivitas elektrokatalitik pada material katalis. Nilai ECSA menunjukkan banyaknya luas permukaan material yang aktif bereaksi dengan elektrolit dalam hal ini $\mathrm{KOH} 1 \mathrm{M}$. Luas permukaan yang dihitung adalah luasan kurva diatas peak reduksi Pd (II) oksida seperti yang dijelaskan Kiyani (2015). Hasilnya dapat dilihat pada Tabel 4.

Nilai ECSA terbesar didapatkan dari material $\operatorname{Pd}(10)$ dibandingkan dengan $\operatorname{Pd}(5)$ dan $\operatorname{Pd}(10)$. Seperti yang telah dibahas sebelumnya hal ini disebabkan pada Pd(15) jumlah Pd yang terlalu banyak akan bertumpuk menutupi luas permukaan grapene sedangkan pada $\operatorname{Pd}(5)$ jumlah $\mathrm{Pd}$ lebih sedikit dibandingkan dengan $\operatorname{Pd}(10)$.

Penambahan Ni meningkatkan luas permukaan $\operatorname{Pd}(15)$ karena Ni dapat membantu Pd dalam proses pembentukan Pd(II) oksida sehingga jumlah Pd (II) oksida yang direduksi menjadi lebih banyak, namun jumlah Ni yang terlalu banyak akan menurunkan luas permukaan aktif. Hal ini disebabkan karena menurut Hsieh (2009) $\mathrm{OH}^{-}$akan cenderung berikatan dengan logam pendukung dari material katalis Pt ataupun Pd dan juga karena menurut Xi (2013) bahwa hidrogenisasi air oleh $\mathrm{Ni}$ menjadi $\mathrm{Ni}-\mathrm{OH}_{\text {ads }}$ sebenarnya membutuhkan energi aktifasi yang cukup besar namun dengan keberadaan Ni energi tersebut turun sehingga $\mathrm{Ni}$ dapat bereaksi lebih cepat dan membantu pembentukan Pd(II) oksida. Namun apabila Ni terlalu banyak maka pembentukan $\mathrm{Pd}-\mathrm{OH}(\mathrm{ads})$ justru akan terhambat karena kesetimbangan reaksi akan bergeser ke arah raktan.

Gambar 11 menjelaskan kurva hasil Uji CV sampel dengan variasi waktu sputtering Pd 15, 10 dan 5 menit dalam elektrolit $\mathrm{KOH}+$ Metanol 1M. Peak oksidasi terlihat pada potensial $-0,3$ sampai $0,1 \mathrm{~V}$ sesuai dengan hasil penelitian Xi (2013).

Pola kurva yang dihasilkan berbeda dengan pola kurva hasil pengujian dengan elektrolit $\mathrm{KOH} 1 \mathrm{M}$. Terdapat peak pada cathodic scan (If) yang merupakan hasil oksidasi methanol oleh Pd yang dapat dituliskan seperti reaksi kimia menurut Yu (2010) [9]. Reaksi tersebut seringkali tidak tuntas sehingga umu diketahui adanya rasio If/Ib yang menunjukkan ketuntasan reaksi.

Hasil Uji CV sampel dengan variasi waktu sputtering Pd 15,10 dan 5 menit. Rasio If/Ib tertinggi berturut-turut $\mathrm{Pd}(10)$ $(23,51)$, kemudian $\operatorname{Pd}(5)(9,71)$, lalu $\operatorname{Pd}(15)(2,11)$ dan densitas arus dari ang tertinggi $\operatorname{Pd}(10)(4,8 \mathrm{~mA} / \mathrm{g})$, kemudian $\operatorname{Pd}(5)(3,67 \mathrm{~mA} / \mathrm{g})$, dan $\operatorname{Pd}(15)(1,44 \mathrm{~mA} / \mathrm{g})$. Urutan tersebut menunjukkan semakin baik kinerja dari katalis dan juga arus yang dihasilkannya.

Gambar 12 menjelaskan kurva hasil uji CV pada sampel dengan waktu sputter Pd 15 menit dan variasi waktu sputter $\mathrm{Ni}$ 5,10 , dan 15 menit. Rasio If/Ib tertinggi berturut-turut $\mathrm{Pd}(15)$ $\mathrm{Ni}(5)$ (47,26), kemudian Pd(15)-Ni(10) (15,22), lalu Pd(15)$\mathrm{Ni}(15)(9,25)$, sedangkan densitas arusnya pun menunjukkan hal serupa dimana densitas tertinggi terdapat pada $\operatorname{Pd}(15)$ $\mathrm{Ni}(5)(4,18 \mathrm{~mA} / \mathrm{g})$, kemudian $\mathrm{Pd}(15)-\mathrm{Ni}(10)(3,25 \mathrm{~mA} / \mathrm{g})$ dan $\mathrm{Pd}(15)-\mathrm{Ni}(15)(3,07 \mathrm{~mA} / \mathrm{g})$. Semakin tinggi rasio If/Ib dan nilai densitas arus artinya semakin baik katalis tersebut mengoksidasi metanol dan tahan terhadap keberadaan $\mathrm{CO}$ dipermukaan. 
Penambahan Ni seperti yang dijelaskan pada penelitian Xi (2013), membantu Pd dalam mengkatalis metanol dimana Pd bertanggung jawab utama mengkatalis metanol membentuk Pd-COads sedangkan Ni akan mengkatalis air membentuk NiOHads. Tanpa adanya $\mathrm{Pd}, \mathrm{Ni}-\mathrm{OH}_{\mathrm{ads}}$ dari katalisis air akan terbentuk pada potensial yang tinggi, terlebih ukuran nano material juga menyebabkan atom $\mathrm{Ni}$ dan Pd bekerja lebih sinergi sehingga luar permukaan dan peak oksidasi nya meningkat.

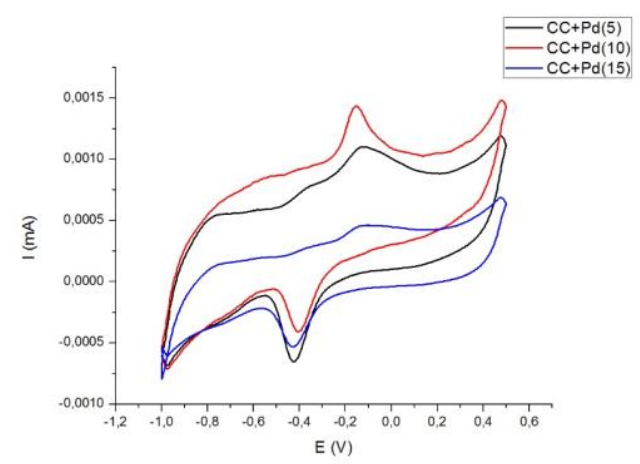

Gambar 11. Kurva hasil pengujian CV elektrolit $\mathrm{KOH}+$ Metanol $1 \mathrm{M}$ pada. CC-Graphene/Pd(5), CC-Graphene/Pd(10), dan CC-Graphene/Pd(15).

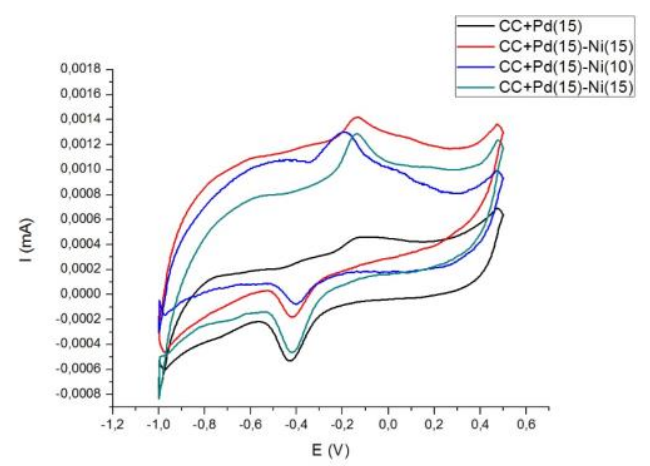

Gambar 12. Kurva hasil pengujian CV elektrolit $\mathrm{KOH}+$ Metanol $1 \mathrm{M}$ pada $\mathrm{CC}$ Graphene/Pd(15), CC-Graphene/Pd(15)-Ni(5), CC-Graphene/Pd(15)-Ni(10), dan CC-Graphene/Pd(15)-Ni(5).

Tabel 4.

Hasil Pengujiam CV

\begin{tabular}{lcrrr}
\hline \hline \multicolumn{1}{c}{ Sampel Uji } & $\begin{array}{c}\text { Kapasitans } \\
\text { i Spesifik } \\
(\mathbf{F} / \mathbf{g})\end{array}$ & $\begin{array}{c}\text { ECSA } \\
\left(\mathbf{m}^{2} / \mathbf{g}\right)\end{array}$ & \multicolumn{1}{c}{ If/Ib } & $\begin{array}{c}\text { Densitas } \\
\text { Arus } \\
(\mathbf{m A} / \mathbf{g})\end{array}$ \\
\hline CC-Graphene & 17,24 & - & - & - \\
CC-G/Ni(15) & 47,45 & - & - & - \\
CC+Pd(5) & 21,16 & 0,731 & 9,71 & 3,67 \\
CC+Pd(10) & 32,86 & 0,747 & 23,51 & 4,80 \\
CC+Pd(15) & 18,95 & 0,235 & 2,11 & 1,44 \\
CC+Pd(15)-Ni(5) & 23,30 & 0,371 & 47,26 & 4,18 \\
CC+Pd(15)-Ni(10) & 27,16 & 0,293 & 15,22 & 3,25 \\
CC+Pd(15)-Ni(15) & 25,92 & 0,286 & 9,25 & 3,07 \\
\hline \hline
\end{tabular}

\section{KESIMPULAN}

Material elektrokatalis berbahan Pd-Ni/Graphene berhasil dibuat dengan metode RF Sputtering berdasarkan hasil karakterisasi XRD dan SEM-EDX. Metode RF Sputtering tidak menyebabkan perubahan kristal pada graphene. Performa terbaik ditunjukan oleh variasi waktu sputtering Pd 10 menit dan variasi sputtering Pd 15 menit ditambah dengan Ni 5 menit. Hal ini dikarenakan hasil evaluasi unjuk kerja elektrokatalis menggunakan pengujian $\mathrm{CV}$ pada dua larutan yakni $\mathrm{KOH} 1 \mathrm{M}$ dan $\mathrm{KOH}+$ Metanol $1 \mathrm{M}$. Pada uji elektrolit $\mathrm{KOH} 1 \mathrm{M}$ didapatkan nilai kapasitansi terbaik pada $\mathrm{Pd}(10)$ yaitu $32,86 \mathrm{~F} / \mathrm{g}$ dan terjadi peningkatan terbaik pada $\mathrm{Pd}(15)$ dengan tambahan Ni sputtering 10 menit yaitu sebesar 8,21 F/g. Sedangkan pada ECSA diperoleh nilai terbaik pada $\mathrm{Pd}(10)$ yaitu $0,747 \mathrm{~m} 2 / \mathrm{g}$ dan terjadi peningkatan terbaik pada $\operatorname{Pd}(15)$ dengan tambahan Ni sputtering 5 menit sebesar 0,136 $\mathrm{m} 2 / \mathrm{g}$. Sedangkan nilai If/Ib terbaik adalah sampel $\mathrm{Pd}(15)-$ $\mathrm{Ni}(5)$ yaitu sebesar 47,26 dengan densitas arus sebesar 4,18 $\mathrm{mA} / \mathrm{g}$.

\section{DAFTAR PUSTAKA}

[1] Serov, A., \& Kwak, C. 2009. "Review of non-platinum anode catalysts for DMFC and PEMFC application". Applied Catalysis B: Environmental, 90(3), 313-320.

[2] Sharma, S., \& Pollet, B. G. 2012. "Support materials for PEMFC and DMFC electrocatalysts-a review". Journal of Power Sources, 208, 96-119.

[3] Singh, V., Joung, D., Zhai, L., Das, S., Khondaker, S. I., \& Seal, S. 2011. "Graphene based materials: past, present and future". Progress in materials science, 56(8), 1178-1271.

[4] Hsieh, C. T., \& Lin, J. Y. 2009. "Fabrication of bimetallic Pt-M (M= $\mathrm{Fe}, \mathrm{Co}$, and $\mathrm{Ni}$ ) nanoparticle/carbon nanotube electrocatalysts for direct methanol fuel cells". Journal of Power Sources, 188(2), 347-352.

[5] Listyana L., Susanti, D, Fajarin R., \& Kurniawan F. 2016. Analisis Pengaruh Temperatur Hidrotermal pada Sintesa Material Graphene terhadap Unjuk Kerja Direct Methanol Fuel Cell (DMFC). Jurnal Teknik ITS.

[6] Ratnasari, D. D, Susanti, D, \& Ardhyananta H. 2016. "Pengaruh Material Graphene Oksida/X dan Graphene/X (X=Au, Pd Dan Pdau) sebagai Elektrokatalis terhadap Unjuk Kerja Direct Methanol Fuel Cell(DMFC)". Jurnal Teknik ITS.

[6] Helmersson, U., Lattemann, M., Bohlmark, J., Ehiasarian, A. P., \& Gudmundsson, J. T. 2006. "Ionized physical vapor deposition (IPVD): A review of technology and applications". Thin Solid Films, 513(1), $1-24$.

[7] Kiyani , R., Rowshanzamir, S., \& Parnian, M. 2015. "Multi-walled carbon nanotubes supported palladium nanoparticles: Synthesis, characterization and catalytic activity towards methanol electro oxidation in alkaline media". Iranian Journal of Hydrogen \& Fuel Cell, 2, 67-74.

[8] Xi, P., Cao, Y., Yang, F., Ma, C., Chen, F., Yu, S., ... \& Zhang, X. 2013. "Facile synthesis of Pd-based bimetallic nanocrystals and their application as catalysts for methanol oxidation reaction". Nanoscale, 5(13), 6124-6130.

[9] Hao Yu, E., Krewer, U., \& Scott, K. 2010. "Principles and Materials Aspects of Direct Alkaline Alcohol Fuel Cells". Energies, 3(8), 14991528. 